\title{
Surgical Pathology
}

National Cancer Institute

\section{Source}

National Cancer Institute. Surgical Pathology. NCI Thesaurus. Code C16958.

A field of anatomical pathology in which tissue or cells removed from a living org anism are macroscopically and microscopically reviewed for the purpose of disease diagnosis. 